\title{
Olfactory Supporting Cell
}

National Cancer Institute

\section{Source}

National Cancer Institute. Olfactory Supporting Cell. NCI Thesaurus. Code C13152.

A cell that serves to provide support and protection to the olfactory epithelium. 